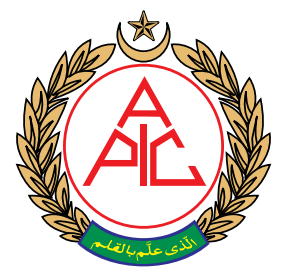

${ }^{1}$ General Physician,

Attock, (Pakistan)

2Orthopedic Surgeon,

Baghdad, (Iraq)

${ }^{3}$ Orthopedic Surgeon,

Shiroi, (India)

Correspondence: Nasser Ali Malik, MBBS, General Physician, Attock, (Pakistan); E-mail: doc.malik14@gmail. com; phone: +923340000203

Received: 29 March 2020;

Reviewed \& Accepted:

5 April 2020

\section{Lignocaine's substantial role in COVID-19 management: Potential remedial and therapeutic implications}

\author{
Nasser Ali Malik*1, Amjid Hammodi², \\ Dayanidhi Ramachandra Jaiswara ${ }^{3}$
}

\begin{abstract}
Background: The outbreak caused by SARS CoV-2 of the recent coronavirus disease-2019 (COVID-19) has been marked as a public health concern with a significant mortality at the global level. Lignocaine a common anesthetic agent being used for pain free surgeries for over a long period of time has expressed extensive characteristic of being an anti-inflammatory, antibacterial, direct spasmolytic, ion channel blocking and repolarization agent. We did a literature review
\end{abstract}

Methodology: Currently compiled over-view has for the first time evaluated the probable curative and therapeutic role of nebulized lignocaine drug against SARS CoV-2 by utilization of PubMed, MEDLINE, NHS Evidence and Web of Science databases.

Results: With evidence of nebulized lignocaine being used successfully in respiratory illness before and the established role of low concentration lignocaine as ion channel repolarization agent, we try to interpret and deduce the possible implication of nebulized lignocaine as possible therapeutic agent and a potential cure against SARS-CoV-2 caused respiratory illness by acting as an anti-inflammatory agent during SARS-CoV-2 caused acute lung injury and also possibly as an antiviral drug.

Conclusion: By the virtue of possessing anti-inflammatory effect and potential antiviral effects, nebulized lignocaine can be a breakthrough in the management of the current COVID-19 pandemic.

Key words: Lignocaine; Nebulized lignocaine; Respiratory illness; Severe Acute Respiratory Syndrome; SARS CoV-2; COVID-19; ion-channels

Citation: Malik NA, Hammodi A, Jaiswara DR. Lignocaine's substantial role in COVID-19 management: Potential remedial and therapeutic implications. Anaesth. pain \& intensive care 2020;24(1):59-63. DOI: https://doi.org/10.35975/apic.v24i1.1227

\section{INTRODUCTION}

Coronavirus disease-2019 (COVID-19) is an infectious disease that causes pneumonia. COVID-19 is third documented transfer of animal coronavirus to human in only two decades leading to an epidemic. The epidemic of COVID-19 began in December 2019 in Wuhan, capital city of Hubei Province,
Peoples Republic of China and by now is declared as global pandemic infecting over half a million people worldwide in more than 180 countries and causing deaths of more than 20,000 people according to latest figures by World Health Organization (WHO). COVID-19 is caused by a novel corona virus previously known as (2019-nCoV by WHO), now known to the world as Severe Acute Respiratory Syndrome Coronavirus 2 (SARS-CoV-2) $\cdot^{1-3}$ 
SARS-CoV-2 is a virus of the same coronavirus family belonging to the Middle East Respiratory Syndrome (MERS-2012) and Severe Acute Respirator Syndrome (SARS-2007) epidemics. SARS-CoV-2 is quite similar to SARS-CoV but with few structural differences. ${ }^{3}$ SARS-CoV-2 has a broader clinical spectrum, the infection caused by it is asymptomatic at times, or a mild upper respiratory tract illness to severe viral pneumonia causing acute lung injury (ALI) leading to acute respiratory distress syndrome (ARDS) and eventually respiratory failure and death. ${ }^{2}$ The frequent complications of COVID-19 include ALI, ARDS, sepsis, respiratory failure and heart failure.

\section{SARS-COV-2 AND ION CHANNELS}

When virus enters host's system, there is an already diversify ionic activities by the host cell suitable for viral proteins. Viral proteins target these ionic channels and form viroporin. ${ }^{4}$ Viroporins play a vital role in virus-cycle propagation and they also prompt the expression viral pathogeneses. ${ }^{4}$ The frequency of $\mathrm{Na}^{+}$intake and $\mathrm{Cl}^{-}$discharge regulate the presence of fluid covering the respiratory surfaces of lungs. ${ }^{5,6}$ Almost all of the respiratory viruses cause viral pathogenesis by inhibiting the amiloridesensitive epithelial $\mathrm{Na}^{+}$Channel (ENaC). Influenza A virus (IAV) inhibits $\mathrm{ENaC}$ thus disrupting the $\mathrm{Na}^{+}$absorption of the epithelial layer leading to inflammation and edema across the epithelial layer of the lung. ${ }^{7-9}$ Respiratory syncytial virus (RSV) infections follow the same process of virulence as of IAV.

Severe acute respiratory corona virus protein $\mathrm{E}$ and $\mathrm{S}$ considerably disrupt the expression of $\mathrm{ENaC}$ protein and hence decreasing the channel activity. ${ }^{4,8}$ SARS coronavirus share a similarity with IAV by inhibiting protein kinase $\mathrm{C}(\mathrm{PKC})$ and increasing the excitability $\mathrm{ENaC}$, leading to inflammation of the epithelial respiratory surface. ${ }^{4,9}$

\section{ARDS AND ION CHANNELS}

COVID-19 causes an injury to the lung parenchyma like the viral pneumonia, leading to ALI or ARDS, and is the leading cause of morbidity and mortality. ARDS is an expeditiously progressive illness during which there is widespread inflammation leading to extensive pulmonary edema causing failure of exchange of gases to eventual lung failure. ${ }^{10,11}$ The gas exchange and fluid balance of lung alveoli is managed by apical amiloride-sensitive epithelial sodium channels $(\mathrm{ENaC})$ and the amiloride-insensitive cyclic nucleotide-gated cation channels (CNG), acting together with the basolaterally located Na-K-ATPase (NKA) promoting transcellular sodium transport. The ion channels modulation regulate alveolar fluid clearance (AFC). ${ }^{12}$ Alveolar fluid reabsorption is of importance in cardiac and non-cardiac injury. ${ }^{11,13,14}$ Any injury to lungs causes a disturbances in $\mathrm{Na}^{+}$and $\mathrm{Cl}^{-}$transport across the membrane thus defectively upregulating $\mathrm{ENaC}$ activity in the airway epithelial cells. This cytokine and chemokine induced inflammation causes disruption in ion-channel function causing improper AFC thus, leading to accumulation of fluid across already inflamed lung epithelium causing eventual fibrosis. ${ }^{14-16} \mathrm{~A}$ novel way to approach ARDS can be by targeting stretch activating ion-channels (SAC) leading to regulation of $\mathrm{ENaC} .{ }^{16,17}$

Table 1: Physicochemical parameters of lignocaine drug

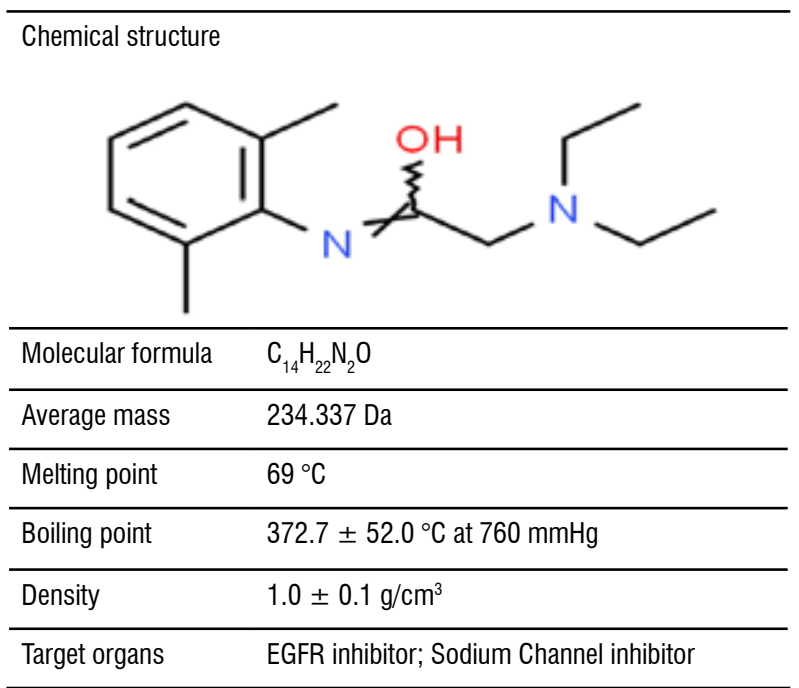

\section{LIGNOCAINE}

Lignocaine, the first amide base local anesthetic and class $1 \mathrm{~b}$ antiarrhythmic drug, is an essential drug on the WHO essential drug list (Table 1). Lignocaine is most commonly used as either a local anesthetic or antiarrhythmic drug, but besides these it has over the years shown its potential as a diverse drug with multiple effects. ${ }^{18}$ It has been recognized as a potent anti-inflammatory medicine, ${ }^{19}$ and its anti-inflammatory properties are at par with nonsteroidal anti-inflammatory drugs (NSAIDs) or even steroids. ${ }^{19,20}$ In long term respiratory illness, it is often considered as steroid sparring drug. ${ }^{20-28}$

Lignocaine being an anti-arrythymic drug is also a cardio-protective drug. By blocking the sodium channels (gates) and repolarizing them, its antiarrhythmic properties are very useful in arrhythmias after myocardial infarction or cardiac surgeries. ${ }^{29-31}$ It also has a good anti-nociceptive properties and has been documented to reduce postoperative pain after 
a peripheral-neural block is applied. Lignocaine also possesses a wide range of in vitro and in vivo characteristics of being an immune-modulator, antibacterial, and anti-cancer agent. ${ }^{32}$

\section{LIGNOCAINE AND REPOLARIZING OF ION-CHANNELS}

Lignocaine marked rank is being an antiinflammatory drug but it is also a very good analgesic too. ${ }^{33}$ It's being used for pain modulation since ages. But the theory of local anesthetic in low dose having a better therapeutic effect was described by Huneke Brothers in 1925. ${ }^{34}$ These effects often are exerted at dose lower than the dose required for a $\mathrm{Na}^{+}$channel blockade. ${ }^{35-37}$

A few recent case studies about newly discovered anatomical points for long term pain management by using a single lignocaine injection in low concentrations, cleared the concept and mechanism that at low dose lignocaine acts by repolarization of depolarized ion channel in the disturbed area. ${ }^{38-41}$

\section{NEBULIZED LIGNOCAINE}

Among off-label frequent use of lignocaine is nebulized form. ${ }^{22,24,40,41}$ It has shown the ability to be very good anti-inflammatory agent by not just decreasing inflammation but also regulating mucus production and fibrosis in vitro and in vivo. ${ }^{13-}$ ${ }^{28}$ There are a number of studies and clinical trials data showing the positive steroid-sparing effects of lignocaine in asthma or retractable cough. ${ }^{25,27,41}$

The systemic absorption of lignocaine in blood after nebulization is very low. Generally as compared to other routes of administrations, in case of nebulized lignocaine usually $100-200 \mathrm{mg}$ for a single dose is considered safe range, with a maximum of $600 \mathrm{mg}$ tolerated.

The concentration of lignocaine $>5 \mathrm{mg} / \mathrm{L}$ is toxic and can lead to tremors, light-headedness, hallucinations or even cardiac arrest. ${ }^{25,40}$

\section{DISCUSSION}

In the light of the facts mentioned, there is strong evidence pointing towards the involvement of ionchannel regulation in the progression of COVID-19 and the potential role of lignocaine in its management. The evidences discussed here clearly show that viral propagation and replication is ion-channel dependent $t^{4,11}$ and the injury caused by the virus to the lung which starts from mild inflammation to ARDS causing pulmonary edema and fibrosis is also governed by cytokines and ion-channels interaction. ${ }^{13-17}$ It is also clear that lignocaine is a potent repolarizing agent when given in diluted low concentration. ${ }^{36-41}$ Therefore, after interpreting all the evidence and our clinical experiences, we suggest that nebulized lignocaine has potential to be used as a drug of choice in the managment of the current COVID-19. ${ }^{19}$ The following is the dose recommended: $5 \mathrm{~mL}$ of $0.6 \%$ lignocaine (either achieved after diluting $1.5 \mathrm{~mL}$ of $2 \%$ lignocaine $+3.5 \mathrm{~mL}$ of distilled water, or by diluting ' $3 \mathrm{ml}$ of 2\% lignocaine $+7 \mathrm{ml}$ of distilled water ) given 6 hourly (4 times in $24 \mathrm{~h}$ ) for the day of start of dry cough in suspected or diagnosed patient. The patient should be NPO for 45 min before and after the administration of nebulized lignocaine. In few patients, the trials have shown lignocaine causes a brief bronchoconstriction, so it is recommended that the administration of the first dose should be monitored and if such episode occurs, a single dose of aerosol salbutamol ${ }^{42}$ before next session of nebulized lignocaine is enough. Along with these necessary precautions to inhibit aerosol transmission of SARS-CoV-2 should also be taken and the nebulization should be done in a controlled environment.

\section{CONCLUSION}

Nebulized lignocaine can be a breakthrough in the management of the current COVID-19 pandemic bearing strong anti-inflammatory effect and potential antiviral agent. A clinical trial of the above theory can substantiate the above theory in this desperate time.

\section{Conflict of interest:}

Nil declared by the authors

\section{Authors' contribution:}

All authors took part in conduct of the study, literature search and manuscript preparation and editing. 


\section{REFERENCES}

1. Wu A, Peng Y, Huang B, Ding X, Wang $X$, Niu P, et al. Genome composition and divergence of the novel coronavirus (2019-nCoV) originating in China. Cell Host Microbe 2020;27(3):325328. [PubMed] [Free Full Text] DOl: 10.1016/i.chom.2020.02.001

2. Zhou F, Yu T, Du R, Fan G, Liu Y, Liu $Z$, et al. Clinical course and risk factors for mortality of adult inpatients with COVID-19 in Wuhan, China: a retrospective cohort study. Lancet 2020;395(10229):1054 1062. [PubMed] [Free Full Text] Dol: 10.1016/S0140-6736(20)30566-3

3. Gorbalenya AE, Baker SC, Baric RS, de Groot RJ, Drosten C, Gulyaeva $A A$, et al. The species Severe acute respiratory syndrome-related coronavirus: classifying 2019-nCoV and naming it SARS-CoV-2. Nat Micro 2020;5:536-544. [PubMed] [Free Full Text] DOI: $10.1038 / \mathrm{s} 41564-020-$ 0695-z

4. Hover S, Foster B, Barr JN, Mankouri $J$. Viral dependence on cellular ion channels - an emerging anti-viral target?. J Gen Virol 2017;98(3):345351. [PubMed] [Free Full Text] Dol: 10.1099/igv. 0.000712

5. O'Grady SM, Lee SY. Chloride and potassium channel function in alveolar epithelial cells. Am J Physiol Lung Cell Mol Physiol 2003;284(5):L689L700. [PubMed] [Free Full Text] DOI: 10.1152/ajplung.00256.2002

6. Aguilar JS, Criado M, De Robertis E. Inhibition by local anesthetics, phentolamine and propranolol of [3H] quinuclydinyl benzylate binding to central muscarinic receptors. Eur J Pharmacol 1980;68(3):317-326. [PubMed] DOl: 10.1016/00142999(80)90529-4

7. Kunzelmann K, Beesley AH, King NJ, Karupiah G, Young JA, Cook DI. Influenza virus inhibits amiloridesensitive $\mathrm{Na}^{+}$channels in respiratory epithelia. Proc Natl Acad Sci USA. 2000;97(18):10282-10287. [PubMed] [Free Full Text] DOl: 10.1073/pnas.160041997

8. Ji HL, Song W, Gao Z, Su XF, Nie HG, Jiang $Y$, et al. SARS-CoV proteins decrease levels and activity of human ENaC via activation of distinct PKC isoforms. Am J Physiol Lung Cell Mol Physiol 2009;296(3):L372L383. [PubMed] [Free Full Text] DOI: 10.1152/ajplung.90437.2008

9. Verdiá-Báguena C, Nieto-Torres JL, Alcaraz A, Dediego ML, Enjuanes L, Aguilella VM. Analysis of SARS-CoVE protein ion channel activity by tuning the protein and lipid charge. Biochem Biophys Acta 2013;1828(9):20262031. [PubMed] [Free Full Text] D0I: 10.1016/i.bbamem.2013.05.008

10. Surya $\mathrm{W}, \mathrm{Li} Y, \quad$ Verdià-Bàguena C, Aguilella VM, Torres J. MERS coronavirus envelope protein has a single transmembrane domain that forms pentameric ion channels. Virus Res 2015;201:61-66. [PubMed] [Free Full Text] DOI: 10.1016/i. virusres.2015.02.023

11. Nieto-Torres JL, Verdiá-Báguena C, Castaño-Rodriguez C, Aguilella VM, Enjuanes L. Relevance of viroporin ion channel activity on viral replication and pathogenesis. Viruses 2015;7(7):3552-3573. [PubMed] [Free Full Text] DOI: 10.3390/ v7072786

12. Donahoe M. Acute respiratory distress syndrome: A clinical review. Pulm Circ 2011;1(2):192-211. [PubMed] [Free Full Text] DOI: 10.4103/2045$\underline{8932.83454}$

13. Hamacher J, Hadizamani $Y$, Borgmann $M$, Mohaupt $M$, Männel DN, Moehrlen U, et al. Cytokine-ion Channel interactions in Pulmonary inflammation. Front Immunol 2018;8:1644. [PubMed] [Free Full Text] DOI: $10.3389 /$ fimmu. 2017.01644

14. Matalon S, Bartoszewski R, Collawn JF. Role of epithelial sodium channels in the regulation of lung fluid homeostasis. Am J Physiol Lung Cell Mol Physiol 2015;309(11):L1229L1238. [PubMed] [Free Full Text] Dol: 10.1152/ajplung.00319.2015

15. Peteranderl C, Sznajder JI, Herold S, Lecuona E. Inflammatory responses regulating alveolar ion transport during pulmonary infections. Front Immunol 2017;8:446. [PubMed] [Free Full Text] DOl: 10.3389/fimmu.2017.00446

16. Wynne BM, Zou L, Linck V, Hoover RS, Ma HP, Eaton DC. Regulation of lung epithelial sodium channels by cytokines and chemokines. Front Immunol 2017:8:766. [PubMed] [Free Full Text] DOI: 10.3389/ fimmu.2017.00766

17. Schwingshackl A. The role of stretchactivated ion channels in acute respiratory distress syndrome: finally a new target?. Am J Physiol Lung Cell Mol Physiol 2016;311(3):L639L652. [PubMed] [Free Full Text] Dol: 10.1152/ajplung.00458.2015

18. Weinberg L, Peake B, Tan C, Nikfarjam M. Pharmacokinetics and pharmacodynamics of lignocaine: A review. World J Anesthesiol 2015;4(2):17-29. [Free Full Text] DOl: 10.5313/wja.v4.i2.17

19. Cassuto J, Sinclair R, Bonderovic M. Anti-inflammatory properties of local anesthetics and their present and potential clinical implications. Acta Anaesthesiol Scand 2006;50(3):265282. [PubMed] [Free Full Text] Dol: 10.1111/i.1399-6576.2006.00936.x

20. Wickström K, Stavréus-Evers A, Vercauteren 0, Olovsson M, Edelstam G. Effect of lignocaine on IL-6, IL-8, and MCP-1 in peritoneal macrophages and endometriotic stromal cells. Reprod Sci 2017;24(3):382-392. [PubMed] DOl: $10.1177 / 1933719116657188$

21. Özyiğit LP, Erer A, Okumuş G, Çağatay T, Kıyan E, Erkan F. Nebulized lidocaine as an alternative therapy for reactive airway dysfunction syndrome. Turk Thorac J 2016;17(2):8283. [PubMed] [Free Full Text] Dol: 10.5578/tti.17.2.017

22. Lv ZM, Chen L, Tang J. Nebulized lidocaine inhalation in the treatment of patients with acute asthma. World 
original research

$J$ Emerg Med 2011;2(1):30-2. [PubMed] [Free Full Text]

23. Slaton RM, Thomas RH, Mbathi JW. Evidence for therapeutic uses of nebulized lidocaine in the treatment of intractable cough and asthma. Ann Pharmacother 2013;47(4):578-585. [PubMed] D0I: 10.1345/aph.1R573

24. Shirk MB, Donahue KR, Shirvani J. Unlabeled uses of nebulized medications. Am J Health Syst Pharm 2006;63(18):1704-1716. [PubMed]

25. Lim KG, Rank MA, Hahn PY, Keogh $\mathrm{KA}$, Morgenthaler TI, Olson EJ. Longterm safety of nebulized lidocaine for adults with difficult-to-control chronic cough: a case series. Chest 2013;143(4):1060-1065. [PubMed] DOI: $10.1378 /$ chest.12-1533

26. Serra MF, Anjos-Valotta EA, Olsen PC, Couto GC, Jurgilas PB, Cotias AC, et al. Nebulized lidocaine prevents airway inflammation, peribronchial fibrosis, and mucus production in a murine model of asthma. Anesthesiol 2012;117(3):580-591. [PubMed] [Free Full Text] DOI: 10.1097/ ALN.0b013e31826687d5

27. Harrison TW, Tattersfield AE. Effect of single doses of inhaled lignocaine on FEV1 and bronchial reactivity in asthma. Respir Med 1998;92(12):1359-1363. [PubMed] [Free Full Text] DOI: 10.1016/s09546111(98)90142-1

28. Constantino RT, Crockett SE, Vasko JS. Cardiovascular effects of lidocaine. Annals Thorac Surg 1969;8(5):425436.

29. Lee $\mathrm{EH}$, Lee $\mathrm{HM}$, Chung $\mathrm{CH}$, Chin $\mathrm{JH}$, Choi DK, Chung HJ, et al. Impact of intravenous lidocaine on myocardial injury after off-pump coronary artery surgery. $\mathrm{Br} \mathrm{J}$ Anaesth 2011;106(4):487-493. [PubMed] [Free Full Text] DOI: 10.1093/bja/ aeq416

30. Spracklen FH, Kimerling JJ, Besterman EM, Litchfield JW. Use of lignocaine in treatment of cardiac arrhythmias. $\mathrm{Br}$ Med J 1968;1(5584):89-91. [PubMed] [Free Full Text]

31. Müller-Edenborn B, Kania G, Osto E, Jakob P, Krasniqi N, BeckSchimmer B, Blyszczuk P, Eriksson U. Lidocaine Enhances Contractile Function of Ischemic Myocardial Regions in Mouse Model of Sustained Myocardial Ischemia. PLoS One. 2016;11(5):e0154699. [PubMed] [Free Full Text] DOI: 10.1371/journal. pone.0154699

32. Atlas of Neural Therapy: With Local Anesthetics 3rd Edition by Mathias Dosch ISBN-13: 978-3131305732.

33. Kuo CP, Jao SW, Chen KM, Wong CS, Yeh CC, Sheen MJ, Wu CT. Comparison of the effects of thoracic epidural analgesia and i.v. infusion with lidocaine on cytokine response, postoperative pain and bowel function in patients undergoing colonic surgery. $\mathrm{Br} J$ Anaesth 2006;97(5):640-646. [PubMed] [Free Full Text] DOI: 10.1093/bja/ael217

34. Aguilar JS, Criado M, De Robertis E. Inhibition by local anesthetics, phentolamine and propranolol of [3H]quinuclydinyl benzylate binding to central muscarinic receptors. Eur J Pharmacol 1980;68(3):317-326. [PubMed] DOI: 10.1016/00142999(80)90529-4

35. Rimbäck G, Cassuto J, Wallin G,
Westlander G. Inhibition of peritonitis by amide local anesthetics. Anesthesiol 1988;69(6):881-886. [PubMed] DOI: 10.1097/00000542198812000-00013

36. Hammodi A. Anatomical gates for pain relief due to cervical and lumbar disc disease. Anaesth Pain Inten Care 2019;23(2):217-220. [ [Free Full Text] DOI: 10.35975/apic.v23i2.1077

37. Hammodi, A. Coccydynia relieved by a tarsal tunnel block: a case series. J Med Case Reports 2019:13:339. [PubMed] [Free Full Text] DOI: 10.1186/s13256-019-2275-5

38. Hammodi A. A case series of cervical disc disease pain relieved by new five injection spots of lignocaine (The anatomical gates of sodium channels blockers of the upper limbs). EC Orthopaed 2020;11(4):06-17. [Free Full Text]

39. Hammodi A. Temporomandibular disorders (TMDs): A new hypothesis. EC Orthopaed 2019;10(9):698-702. [Free Full Text]

40. Ruchika N. Lidocaine -an old drug for new indication. J Int Pharm Sci Drug Res 2013;5:84-87.

41. Burburan SM, Xisto DG, Rocco PR. Anaesthetic management in asthma. Minerva Anestesiol 2007;73(6):357365. [PubMed]

42. Groeben $H$, Silvanus $M T$, Beste $M$, Peters J. Combined lidocaine and salbutamol inhalation for airway anesthesia markedly protects against reflex bronchoconstriction. Chest 2000;118(2):509-515 [PubMed] DOI: $\underline{10.1378 / \text { chest.118.2.509 }}$ 